\title{
A New Fe-C Porous Filter Material From Dredged Sediment: Preparation, Characterization, And Its Application
}

\author{
Shuyi Chu \\ Wenzhou University \\ Qian Qu \\ Wenzhou University \\ Keke Pan \\ Wenzhou Vocational College of Science and Technology \\ Yunjie Xu \\ Agricultural and Rural Bureau of Wencheng County \\ Jibo Xiao ( $\sim$ jbxiao@126.com) \\ Wenzhou University https://orcid.org/0000-0003-0431-3859
}

\section{Research Article}

Keywords: dredged sediment, EDS, XRD, polluted river water, biofilter

Posted Date: June 7th, 2021

DOI: https://doi.org/10.21203/rs.3.rs-504297/v1

License: (c) (1) This work is licensed under a Creative Commons Attribution 4.0 International License. Read Full License

Version of Record: A version of this preprint was published at Environmental Science and Pollution Research on July 31st, 2021. See the published version at https://doi.org/10.1007/s11356-021-15642-3. 


\section{Abstract}

A new Fe-C porous filter material was prepared with dredged sediment of river as raw material. The orthogonal test $L_{9}\left(3^{4}\right)$ and component ratio experiment of raw material were conducted to investigate the optimum technological condition. Further, the filter obtained was characterized by Brunauer-Emmett-Teller (BET), scanning electron microscopy (SEM), energy dispersive X-ray spectroscope (EDS), and X-ray diffraction (XRD). Results showed that the optimal technological condition was sludge: straw: starch: iron powder: foam: iron powder $74.5: 10: 7.5: 3: 5$, preheating temperature $280^{\circ} \mathrm{C}$, preheating $15 \mathrm{~min}$, sintering temperature $1080{ }^{\circ} \mathrm{C}$, and sintering $11 \mathrm{~min}$. The BET surface area of the filter was $3.32 \mathrm{~m}^{2} \mathrm{~g}^{-1}$, and average pore size was $10.05 \mathrm{~nm}$. Phase composition mainly included $\mathrm{SiO}_{2}, \mathrm{Fe}_{3} \mathrm{O}_{4}, \mathrm{Fe}_{2} \mathrm{O}_{3}$ and muscovite $\left(\mathrm{KAl}_{2}\left(\mathrm{Si}_{3} \mathrm{Al}\right) \mathrm{O}_{10}(\mathrm{OH})_{2}\right)$. Average effluent concentrations of total phosphorus (TP), total organic carbon (TOC), and total nitrogen (TN) of the biofilter system filled with the filter obtained were decreased to $0.08,3.43$, and 3.76 $\mathrm{mg} \mathrm{L}^{-1}$, separately, at hydraulic retention time $4 \mathrm{~h}$. Thus, the filter prepared with dredged sediment of rive as raw material is an alternative material for polluted river water purification.

\section{Introduction}

Sediment is an important constitute of aquatic ecosystem. It acts as a potential sink of many water pollutants including organic carbon, nutrients, and heavy metals (Zhang et al., 2009; Schindler et al., 2016; Benamar et al., 2019). Nonetheless, it is also primary pollutant source of the waters. When environmental conditions change, or disturbed by benthos activities, the contaminants in the sediment would release into the overlying water, and contribute to a decline in water quality (Wu et al., 2012; Douglas et al., 2016; Gu et al., 2019; Oldenborg and Steinman, 2019). The internal contaminants from the sediment are considered as the predominant cause of water pollution as the external loading is effectively reduced or limited (Puttonen et al., 2016; Schonach et al., 2018). Thus, control endogenous sediment contamination is of significant importance for the improvement of water quality, and has already attracted considerable attention (Patmont et al., 2015; Benamar et al., 2019; Song et al., 2020).

Dredging is the most commonly used method to reduce the internal loading sediment contaminants release in lakes or rivers around the world (Zhong et al., 2008; Chen et al., 2018). Previous studies and practical engineering have confirmed that dredging could effectively reduce excess nutrients, organic matter, heavy metals in the active surface sediment (Zhong et al., 2008; Yu et al., 2017). Considerable volumes of sediments are dredged annually in the world (Dubois et al., 2009). In China, more than 100 million $\mathrm{m}^{3}$ of sediment are dredged per year (Amar et al., 2021). However, due to the potential content of toxic substances in the sediment, how to dispose of the sediment is a key problem.

Beneficial reuse of dredge sediment is a growing practice worldwide (Cappuyns et al., 2015; Wang et al., 2015; Mymrin et al., 2017; Amar et al., 2021). Sediment was used to be processed at high temperature, producing concrete (Tay et al., 2001; Agostini et al., 2007; Benzerzour et al., 2017), bricks (Lim et al., 2019), and ceramsite (Qi et al., 2016; Jin et al., 2019) instead of clay due to its fine particles, strong plasticity and binding force. Through the sintering process, the pathogens are killed, the heavy metals are properly stabilized and the organic pollutants might be volatized out (Lafhaj et al., 2008).

Iron-carbon micro-electrolysis (ICME) has been proven to be a promising advanced oxidation process for various pollutants (Yang et al. 2017). It was based on galvanic cell formed by the anode (iron) and cathode (carbon) in the electrolyte (wastewater). At the anode, the iron loses two electrons to form $\mathrm{Fe}^{2+}$, and then be oxidized to $\mathrm{Fe}^{3+}$ under aerobic condition (Shen et al., 2019). The Fe ${ }^{2+}$ and Fe ${ }^{3+}$ could react with dissolved phosphorus to form iron phosphate precipitates. The $[\mathrm{H}]$ produced by the reduction reaction at the cathode have high chemical activity, and can destroy the carbon chains of organic contaminants effectively (Ding et al., 2021). Besides, $\mathrm{Fe}^{2+}$ and $[\mathrm{H}]$ may give rise to hydrogen autotrophic denitrification and Fe autotrophic denitrification (Xing et al., 2013). The combination of ICME with constructed wetland has attracted extensive attention in recent years (Zhou et al., 2017; Zheng et a., 2019; Ma et al., 2021 ).

The purpose of the study is to prepare Fe-C porous filter material, which could be used directly in the biofilter system or as substrate of wetland, with dredged sediment as raw material. Additives such as straw, starch, waste iron powder, and foam were used, and the dredged sediment and straw were pretreated with zinc chloride solution in order to improve the pore structure of the filter obtained. Thus, the primary objective of this study was to (1) investigate the effects of additive amount, preparation conditions including preheating temperature, preheating time, incinerating temperature and incinerating time on properties of the filter obtained; (2) explore the characteristics of the filter by Brunauer-Emmett-Teller (BET), scanning electron microscopy (SEM), energy dispersive X-ray spectroscope (EDS), and X-ray diffraction (XRD); and (3) evaluate the potential application of the filter for polluted river water 
purification. The results of the study might provide a feasible approach for beneficial reuse of dredged sediment, and a new material for the biofilter system or the wetland.

\section{Materials And Methods}

\section{Raw materials and polluted river water}

Dredged sediment was fetched from the river in Longwan district, Wenzhou City, Zhejiang Province. It was black and odorous. The main components (mass percent) were as follows (data from XRF analysis): $\mathrm{SiO}_{2} 63.51 \%, \mathrm{Al}_{2} \mathrm{O}_{3} 17.21 \%, \mathrm{Fe}_{2} \mathrm{O}_{3} 6.53 \%, \mathrm{CaO} 0.96 \%, \mathrm{MgO}$ $3.65 \%, \mathrm{Na}_{2} \mathrm{O} 1.71 \%, \mathrm{~K}_{2} \mathrm{O} 2.89 \%$, Zn 0.0746\%, Cu 0.0216\%, $\mathrm{Cr} 0.0353 \%, \mathrm{~Pb} 0.0084 \%$, and burning rate reduction $10.9 \%$. The sediment was air-dried, then dried at $105^{\circ} \mathrm{C}$ in the oven for $1 \mathrm{~h}$, and ground by a crusher machine. Rice straw was obtained from a paddy field near Wenzhou University, carefully washed with tap water, air-dried, and ground up using a crusher machine to a length of 2-5 mm. Both the sediment and ground straw were then soaked thoroughly in zinc chloride solution ( $\left.3.0 \mathrm{~mol} \mathrm{~L}^{-1}\right)$ at a mass ratio of $4: 1$ for $20 \mathrm{~h}$, and then dried at $105^{\circ} \mathrm{C}$ in the oven for $12 \mathrm{~h}$, and subsequently ground, and passed through a 100-mesh sieve. The foam was purchased, also ground and passed through a 100 -mesh sieve.

The polluted river water was derived from the river in Wenzhou University. Concentrations of total phosphorus (TP), total organic carbon (TOC), ammonium nitrogen $\left(\mathrm{NH}_{4}-\mathrm{N}\right)$, and total nitrogen (TN) were 0.16-0.80, 3.41-6.89, 3.65-8.19, and 3.79-8.29 $\mathrm{mg} \mathrm{L}^{-1}$, respectively, and the $\mathrm{pH}$ was among 6.9 to 8.9 .

\section{Preparation of Fe-C porous filter}

The sediment was sampled and mixed with straw, starch, foam, iron powder, and tap water using 50 pelletizing machine to pelletize raw body with particle size of $5-8 \mathrm{~mm}$. The samples were dried at $105^{\circ} \mathrm{C}$ for $210 \mathrm{~min}$, and then pyrolyzed in a muffle furnace. The temperature was ramped up from ambient to preheating temperature, and then to a final temperature with a retention time at an increase rate of $3{ }^{\circ} \mathrm{C} \mathrm{min}^{-1}$. The resultant material was cooled naturally, and the filter was obtained.

Phosphorus and organic carbon removal properties of the filter were conducted: $300 \mathrm{~g}$ filter was added in $1 \mathrm{~L}$ miscellaneous drainage, and the sample was collected for analysis of TP and TOC concentrations after $12 \mathrm{~h}$. TP and TOC concentrations of the raw sewage were 4-10, and 10-45 $\mathrm{mg} \mathrm{L}^{-1}$, separately.

\section{Characterization of the filter}

The specific surface area and pore structure were measured using an accelerated surface area and porosimetry system (USA, Micromeritics ASAP 2010) using $\mathrm{N}_{2}$ gas as adsorbate at 77.37K. A field emission SEM was used to observe the physical morphology and micro-structure. The element composition was identified and quantified by the EDS. The crystal structure was analyzed with the XRD. Leaching of potentially toxic metals in the filter was conducted according to Chinese standard methods (GB5085.3-2007).

\section{Dynamic purification test for polluted river water}

The test was conducted in the biofilter $(\mathrm{FB}, 45 \mathrm{~cm} \star 30 \mathrm{~cm} \star 45 \mathrm{~cm}$ ) system (Fig. 1). Initially, the river water was equalized in the storage tank $(120 \mathrm{~cm} * 70 \mathrm{~cm} * 60 \mathrm{~cm})$, and fed to the bottom of FB continuously using a diaphragm metering pump. Four parallel FBs were adopted: 1. Control; 2. Aeration with no filter; 3 . Filter only; 4 . Aeration with filter. The hydraulic retention time was $4 \mathrm{~h}$. The packing height of the filter was $20 \mathrm{~cm}$. Air compressor was used to provide air to BFs 2 and 4 at a flow rate of $300 \mathrm{ml} \mathrm{min}^{-1}$. Samples were collected for analysis, each with three sampling replicates.

\section{Analytical methods}

Temperature, pH, ORP, and DO were estimated using a portable DO meter (HQ40d, Hatch Company) multi-parameter monitor. $\mathrm{NH}_{4}{ }^{+} \mathrm{N}$, $\mathrm{NO}_{3}{ }^{-}-\mathrm{N}, \mathrm{NO}_{2}{ }^{-} \mathrm{N}$ and TP were measured according to the Chinese SEPA standard methods (SEPA, 2002). TN and TOC were determined by a simultaneous TOC/TN analyser (TOV-VCPH, Shimadzu Japan). Breaking and wear rate, void fraction, water absorption, and porosity were determined according to Chinese Standard Methods: Lightweight aggregates and its test methods (GB/T 17431.2-2010), and artificial ceramsite filter material for water treatment (CJ/T 229-2008). Metal ions were detected using inductively coupled plasma optical emission spectroscopy (ICP-OES, Optima 8000, Perkin Elmer). 
Results And Discussion

\section{Preparation of Fe-C porous filter}

\section{Optimization of operational parameters}

Based on one-factor pre-experiment, an orthogonal experimental design of four factors (preheating temperature, preheating time, sintering temperature, sintering time) and three levels were conducted to optimize the process parameters, and removals of TP and TOC were employed as the evaluation index. Table 1 summarizes the results of $L_{9}\left(3^{4}\right)$. The range analysis indicated that sintering temperature was the most important factor for TP removal, while the preheating temperature was the most important for TOC removal. Appropriate process parameters were preheating temperature $280^{\circ} \mathrm{C}$, preheating time $15 \mathrm{~min}$, sintering temperature $1080{ }^{\circ} \mathrm{C}$, and sintering time $11 \mathrm{~min}$, separately. The corresponding TOC and TP removals were $44.4 \%$ and $75.2 \%$, and physical properties including breaking and wear rate, porosity, water absorption, and void fraction of the filter obtained were $2.63 \%, 31.2 \%, 22.7 \%$, and $56.5 \%$, respectively, satisfying the Chinese Standard of CJ/T 229-2008 and GB/T 17431.2-2010.

Table 1

Performance indexes values of orthogonal test

\begin{tabular}{|c|c|c|c|c|c|c|c|c|c|c|c|}
\hline Test case & \multicolumn{2}{|c|}{$\begin{array}{l}\text { Horizontal } \\
\text { combination }\end{array}$} & $\begin{array}{l}\text { Breaking } \\
\text { and wear } \\
\text { rate } / \%\end{array}$ & \multicolumn{2}{|c|}{ Void fraction/\% } & Porosity/\% & \multicolumn{2}{|c|}{$\begin{array}{l}\text { Water } \\
\text { absorption/\% }\end{array}$} & $\begin{array}{l}\text { TP } \\
\text { removal/\% }\end{array}$ & \multicolumn{2}{|c|}{ TOC removal/\% } \\
\hline 1 & \multicolumn{2}{|c|}{$\mathrm{A}_{1} \mathrm{~B}_{1} \mathrm{C}_{1} \mathrm{D}_{1}$} & 2.63 & \multicolumn{2}{|c|}{56.5} & 31.2 & \multicolumn{2}{|c|}{22.7} & 44.4 & \multicolumn{2}{|c|}{75.2} \\
\hline 2 & \multicolumn{2}{|c|}{$A_{1} B_{2} C_{2} D_{2}$} & 3.56 & \multicolumn{2}{|c|}{57.4} & 30.8 & \multicolumn{2}{|c|}{25.6} & 37.0 & \multicolumn{2}{|c|}{75.9} \\
\hline 3 & \multicolumn{2}{|c|}{$\mathrm{A}_{1} \mathrm{~B}_{3} \mathrm{C}_{3} \mathrm{D}_{3}$} & 2.84 & \multicolumn{2}{|c|}{55.6} & 33.6 & \multicolumn{2}{|c|}{23.3} & 29.6 & \multicolumn{2}{|c|}{75.4} \\
\hline 4 & \multicolumn{2}{|c|}{$\mathrm{A}_{2} \mathrm{~B}_{1} \mathrm{C}_{2} \mathrm{D}_{3}$} & 2.28 & \multicolumn{2}{|c|}{55.9} & 35.6 & \multicolumn{2}{|c|}{28.8} & 34.6 & \multicolumn{2}{|c|}{75.0} \\
\hline 5 & \multicolumn{2}{|c|}{$\mathrm{A}_{2} \mathrm{~B}_{2} \mathrm{C}_{3} \mathrm{D}_{1}$} & 2.19 & \multicolumn{2}{|c|}{55.5} & 32.4 & \multicolumn{2}{|c|}{21.7} & 26.4 & \multicolumn{2}{|c|}{74.6} \\
\hline 6 & \multicolumn{2}{|c|}{$\mathrm{A}_{2} \mathrm{~B}_{3} \mathrm{C}_{1} \mathrm{D}_{2}$} & 2.26 & 56 & & 32.0 & 24.7 & & 29.7 & 70 & \\
\hline 7 & $\mathrm{~A}_{3} \mathrm{~B}$ & & 1.65 & 53 & & 27.4 & 17.2 & & 28.4 & 75 & \\
\hline 8 & $\mathrm{~A}_{3} \mathrm{~B}$ & & 1.22 & 51 & & 36.0 & 30.9 & & 25.7 & 75 & \\
\hline 9 & $\mathrm{~A}_{3} \mathrm{~B}$ & & 1.50 & 49 & & 37.1 & 29.0 & & 39.5 & 74 & \\
\hline $\begin{array}{l}\text { Breaking } \\
\text { and wear }\end{array}$ & $\mathrm{K}_{1}$ & 3.01 & 2.19 & 2.04 & 2.11 & $\begin{array}{l}\text { Void } \\
\text { fraction/\% }\end{array}$ & $\mathrm{K}_{1}$ & 56.5 & 55.2 & 55.0 & 53.9 \\
\hline rate $/ \%$ & $\mathrm{~K}_{2}$ & 2.24 & 2.32 & 2.45 & 2.49 & & $\mathrm{~K}_{2}$ & 56.0 & 54.9 & 54.4 & 55.7 \\
\hline & $\mathrm{K}_{3}$ & 1.46 & 2.20 & 2.23 & 2.11 & & $\mathrm{~K}_{3}$ & 51.6 & 54.0 & 54.7 & 54.5 \\
\hline & $\mathrm{R}$ & 1.55 & 0.14 & 0.41 & 0.38 & & $\mathrm{R}$ & 4.88 & 1.15 & 0.63 & 1.78 \\
\hline $\begin{array}{l}\text { Porosity } \\
/ \%\end{array}$ & $\mathrm{~K}_{1}$ & 31.9 & 31.4 & 33.1 & 33.6 & $\begin{array}{l}\text { Water } \\
\text { absorption/\% }\end{array}$ & $\mathrm{K}_{1}$ & 23.9 & 22.9 & 26.1 & 24.5 \\
\hline & $\mathrm{K}_{2}$ & 33.4 & 33.1 & 34.5 & 30.1 & & $\mathrm{~K}_{2}$ & 25.0 & 26.0 & 27.8 & 22.5 \\
\hline & $\mathrm{K}_{3}$ & 33.5 & 34.2 & 31.1 & 35.1 & & $\mathrm{~K}_{3}$ & 25.7 & 25.6 & 20.7 & 27.6 \\
\hline & $\mathrm{R}$ & 1.64 & 2.80 & 3.40 & 4.99 & & $\mathrm{R}$ & 1.81 & 3.15 & 7.04 & 5.17 \\
\hline $\begin{array}{l}\text { TP } \\
\text { removal/\% }\end{array}$ & $\mathrm{K}_{1}$ & 37.0 & 35.8 & 33.3 & 36.8 & $\begin{array}{l}\text { TOC } \\
\text { removal/\% }\end{array}$ & $\mathrm{K}_{1}$ & 75.5 & 75.2 & 73.6 & 74.9 \\
\hline & $\mathrm{K}_{2}$ & 30.2 & 29.7 & 37.0 & 31.7 & & $\mathrm{~K}_{2}$ & 73.2 & 75.3 & 75.3 & 73.8 \\
\hline & $\mathrm{K}_{3}$ & 31.2 & 32.9 & 28.1 & 30.0 & & $\mathrm{~K}_{3}$ & 75.3 & 73.4 & 75.1 & 75.3 \\
\hline & $\mathrm{R}$ & 6.81 & 6.08 & 8.89 & 6.79 & & $\mathrm{R}$ & 2.34 & 1.90 & 1.70 & 1.51 \\
\hline
\end{tabular}


Effects of additive including straw, starch, iron powder, and foam on physical characteristics, TOC and TP removals of the filter were investigated based on the optimal operational condition and results were shown in Table 2. Physical characteristics of all filter satisfied the standard of CJ/T 299-2008 and GB/T 17431.2-2010. TOC removal increased by $9.1 \%$ as the content of straw increased from 5$10 \%$. During the pyrolysis process, the hemicellulose and cellulose in the straw were thermally decomposed and produce condensable vapors, and gas, which improved the pore structure of the filter. Besides, it yields biochar, which could form ICME with iron in the filter, enhancing the removal of organic carbon. However, TP removal did not change significantly. It may be attributed to the phosphorus content in the straw.

Table 2 Effect of mixing ratio of raw material on characteristics of the filter

\begin{tabular}{|c|c|c|c|c|c|}
\hline & $\begin{array}{l}\text { Sediment:straw:starch:iron powder: } \\
\text { foam }\end{array}$ & $\begin{array}{l}\text { Physical } \\
\text { characteristics }\end{array}$ & Pelletization & $\begin{array}{l}\text { TP } \\
\text { removal/\% }\end{array}$ & $\begin{array}{l}\text { TOC } \\
\text { removal/\% }\end{array}$ \\
\hline \multirow[t]{3}{*}{ straw } & $78.5: 5: 10: 5: 1.5$ & Standard & easy & 49.2 & 66.2 \\
\hline & 76:7.5:10:5:1.5 & Standard & easy & 48.1 & 72.4 \\
\hline & 73.5:10:10:5:1.5 & Standard & easy & 48.9 & 75.3 \\
\hline \multirow[t]{3}{*}{ starch } & $78.5: 10: 5: 5: 1.5$ & Standard & easy & 45.3 & 76.6 \\
\hline & 76:10:7.5:5:1.5 & Standard & easy & 54.7 & 78.5 \\
\hline & 73.5:10:10:5:1.5 & Standard & easy & 48.9 & 75.3 \\
\hline \multirow{4}{*}{$\begin{array}{l}\text { iron } \\
\text { powder }\end{array}$} & 78.5:10:7.5:2.5:1.5 & Standard & easy & 58.2 & 73.5 \\
\hline & $76: 10: 7.5: 5: 1.5$ & Standard & easy & 62.0 & 64.8 \\
\hline & 73.5:10:7.5:7.5:1.5 & Standard & easy & 68.0 & 55.8 \\
\hline & 71:10:7.5:10:1.5 & Standard & easy & 69.4 & 47.2 \\
\hline \multirow[t]{4}{*}{ foam } & $76: 10: 7.5: 5: 1.5$ & Standard & easy & 54.3 & 56.0 \\
\hline & $75.5: 10: 7.5: 5: 2$ & Standard & easy & 65.1 & 64.2 \\
\hline & $74.5: 10: 7.5: 5: 3$ & Standard & easy & 67.8 & 83.8 \\
\hline & 74:10:7.5:5:3.5 & Standard & difficult & 65.5 & 58.1 \\
\hline
\end{tabular}

Both TOC and TP removals showed a trend of increase followed by a decrease with the increase of starch or foam. The maximum TOC and TP removals were obtained at starch $7.5 \%$ and foam $3 \%$. The values were $78.5 \%$ and $54.7 \%$, and $83.8 \%$ and $67.8 \%$, separately. Starch and foam were versatile binder and pore-forming materials, favorable for the information of abundant pores. However, too much starch may lead to the enlargement of the pore diameter and decline of surface area due to the aggregation of starch-water mixture. The overabundant of foam in the raw materials would reduce the mechanical strength. The raw body was hard to form the expected shape at foam content $4 \%$ in the experiment.

Phosphorus removal increased gradually with the increase of iron powder, with the maximum value of $69.4 \%$ at iron content of $10 \%$. It may be described to the combination of iron ion and phosphorus. However, TOC removal decreased when iron increased from $2.5-10 \%$. This result was completely contrary to our expectation that increase of iron could enhance the ICME process in the filter. The probable reason for this was the eutectic temperature property of iron and iron oxide. They promoted the flux of liquid phase, and subsequently prevented the volatile gas from releasing and formed a denser sinter body with low porous structure. Shih et al. (2006) and Xu et al. (2009) reported that melting point of samples was lowered by the presence of higher $\mathrm{Fe}_{2} \mathrm{O}_{3}$ contents, enhancing the formation of liquid phases and $\mathrm{FeO}$ with higher viscosity. During the sintering process, we also found the leakage of iron at high iron amount, consequently reducing the iron content in the filter.

\section{Characterization of the filter}

Textural morphological characteristics 
The surface of the filter was rough and irregular. Abundant pores, small grooves and cracks were observed on the surface of the material (Fig. 2). The SEM on the cross section showed pores of different sizes and shapes, and agglomerated crystals. BET surface area was $3.32 \mathrm{~m}^{2} \mathrm{~g}^{-1}$, and total volume of mesopore and macropore was $0.00662 \mathrm{~cm}^{3} \mathrm{~g}^{-1}$, with average pore diameter of $10.05 \mathrm{~nm}$. Pore distribution showed that the mesopore accounted for $85.2 \%$ of whole pores.

\section{EDS analyses}

Element composition analysis by EDS revealed that the filter was essentially an association of $\mathrm{O}, \mathrm{Si}, \mathrm{Al}, \mathrm{Fe}, \mathrm{Zn}, \mathrm{K}, \mathrm{Ca}, \mathrm{C}, \mathrm{S}$, and Mg atoms (Fig. 3a). The Si and Al made up the whole skeleton structure, supporting the mechanical strength of the filter. Metal ions including $\mathrm{Fe}, \mathrm{Zn}, \mathrm{K}, \mathrm{Ca}$, Al were effective to combine with phosphate to remove the phosphorus from the wastewater. The Fe and $\mathrm{C}$ may inform the ICME, consequently enhancing the degradation of organic matter.

\section{Crystalline phase (XRD) analyses}

Figure $3 \mathrm{~b}$ shows the XRD pattern of the filter. The main minerals included quartz $\left(\mathrm{SiO}_{2}\right)$, magnetite $\left(\mathrm{Fe}_{3} \mathrm{O}_{4}\right)$, hematite $\left(\mathrm{Fe}_{2} \mathrm{O}_{3}\right)$ and a new crystallized muscovite $\left(\mathrm{KAl}_{2}\left(\mathrm{Si}_{3} \mathrm{Al}\right) \mathrm{O}_{10}(\mathrm{OH})_{2}\right)$. The muscovite was a member of the mica group of silicate minerals with strongly layered sheet like structure, thus enhancing the mechanical strength and breaking tenacity of the filter.

\section{Leaching of potential toxic metals}

In order to investigate the environmental safety of the filter, heavy metal leaching test was performed. The highest concentrations of $\mathrm{Zn}$

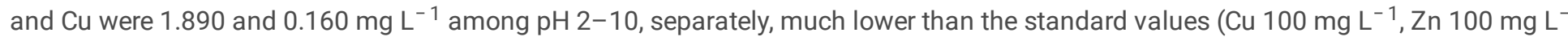
$\left.{ }^{1}\right)$. Both $\mathrm{Pb}$ and $\mathrm{Cr}$ were not detected in the leachate.

\section{Dynamic purification test for polluted river water}

\section{P removal}

Total phosphorus concentrations in the effluents of $3 \#$ and $4 \#$ were significantly lower than those of $1 \#$ and $2 \#$, suggesting the filter effectively improved $P$ removal from the polluted river water. During the test, the influent TP concentration was $0.16-0.80 \mathrm{mg} \mathrm{L}^{-1}, \mathrm{TP}$ concentrations in effluents of $3 \#$ and $4 \#$ were decreased to among $0-0.14 \mathrm{mg} \mathrm{L}^{-1}$, respectively. Aeration could not enhance $\mathrm{P}$ removal effectively as effluent TP concentration difference either between $3 \#$ and $4 \#$, or between $1 \#$ and $2 \#$ was not distinct significantly. The result indicated that $\mathrm{P}$ was removed mainly via adsorption by the filter. Effluent TP concentrations both in $3 \#$ and $4 \#$ did not change greatly in the test, demonstrating the filter was effective yet to remove $\mathrm{P}$ after 35 days of continuous operation.

\section{Organic carbon removal}

As shown in Fig. 5, effluent TOC concentrations in effluents of $3 \#$ and $4 \#$ were lower than 1\# and 2\#, and the differences were significant at higher influent TOC concentration. Aeration enhanced TOC removal by the filter. When influent TOC concentration was

3.41-6.89 $\mathrm{mg} \mathrm{L}^{-1}$, average effluent TOC concentration of $4 \#$ was $11.4 \%$ lower than $3 \#$. This results might indicate that the organic matter removal by the filter was attributed to the degradation by microorganism adhered to the surface of the filter, and the ICME process. Furthermore, the aeration was favorable to the micro-electrolysis process. This was consistent with observations of Han et al. (2016). They reported that the aeration not only improved the micro-electrolysis process, but also protected the filter from harden and desactivation. Therefore, the aerated biofilter with the filter might be a feasible alternative for removing organic carbon matter.

\section{N removal}

The differences in concentration variations of $\mathrm{NH}_{4}{ }^{+}-\mathrm{N}$, and TN in 1\#, 2\#, 3\#, and 4\# were similar with TOC (Fig. 6). Effluent $\mathrm{NH}_{4}{ }^{+}-\mathrm{N}$ concentrations in four treatments were 3.54-7.30, 3.32-7.08, 1.99-6.92, and 1.60-6.80 mg L ${ }^{-1}$ separately, at influent $\mathrm{NH}_{4}{ }^{+}-\mathrm{N}$ concentration 3.65-8.19 $\mathrm{mg} \mathrm{L}^{-1}$. While effluent TN concentrations were 4.30-7.46, 3.43-7.24, 2.30-7.05, and 1.81-6.94 respectively. Thus, the filter was effective to remove nitrogen in the waters, and aeration could enhance the process. However, nitrate concentrations in all treatments were not distinct between effluent and influent, and the values were less than $0.3 \mathrm{mg} \mathrm{L}^{-1}$. It may indicate that nitrogen in the water was removed mainly through adsorption by the filter. Nitrification and denitrification process were little. The reason for this may be ascribed to the low microorganism content in the raw river water, and low propagation rate of the microorganism for insufficient nutrient in the water. 


\section{Environmental safety evaluation}

During the operation, effluent $\mathrm{pH}$ of $3 \#$ and $4 \#$ was similar with the influent, and the value was among 7.0-8.4. Concentrations of $\mathrm{Cu}$, $\mathrm{Zn}$, and Fe were $0.001-0.003,0.002-0.003,0.002-0.011 \mathrm{mg} \mathrm{L}^{-1}$, separately, much lower than the class 1 standard value of environmental quality standards for surface water. Both $\mathrm{Pb}$ and $\mathrm{Cr}$ were not detected in the effluents.

\section{Conclusions}

In the present study, a Fe-C porous filter material was prepared with dredged sediment as main raw material, and straw, starch, foam and waste iron powder as additive. The optimal conditions were preheating $280^{\circ} \mathrm{C}$, preheating $15 \mathrm{~min}$, sintering temperature $1080{ }^{\circ} \mathrm{C}$, sintering time 11 min at sediment: straw: starch: foam: iron 74.5:10:7.5:3:5. The BET surface area of the filter obtained was $3.32 \mathrm{~m}^{2} \mathrm{~g}^{-1}$,

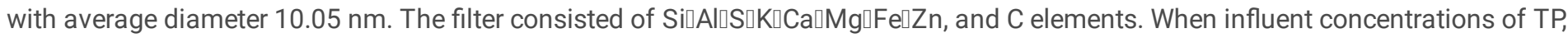
TOC, $\mathrm{NH}_{4}-\mathrm{N}$, and TN were 0.16-0.80, 3.41-6.89, 3.65-8.19, and 3.79-8.29 $\mathrm{mg} \mathrm{L}^{-1}$, average effluent TP, TOC, $\mathrm{NH}_{4}-\mathrm{N}$, and TN concentrations of the biofilter system filled with the filter were $0.08,3.43,3.61$, and $3.76 \mathrm{mg} \mathrm{L}^{-1}$ separately at HRT $4 \mathrm{~h}$. Aeration enhanced organic carbon and nitrogen removals. Heavy metals concentrations in the effluent were much lower than class 1 standard of environmental quality standards for surface water during the continuous operation process. Therefore, the filter is a potential material for the biofilter system.

\section{Declarations}

\section{Ethical Approval}

Not applicable

\section{Consent to Particulate}

Not applicable

\section{Consent to Publish}

Not applicable

\section{Author Contributions}

Chu SY wrote the manuscript; Qu Q carried out the experiments; Xiao JB and Chu SY designed the experiments, analysed the data and revised the manuscript; Xu YJ contributed ideas for the experiments; Pan KK revised the manuscript.

\section{Funding}

This work was supported by Zhejiang Province Public Welfare Technology Application Research Project (LGF21E090002), and the Science and Technology Program of Wenzhou, China (No.S20190003; ZG2020024).

\section{Competing Interests}

The authors declare that they have no competing interests.

\section{Availability of data and materials}

All data generated or analysed during this study are included in this published article.

\section{References}

1. Agostini F, Skoczylas F, Lafhaj Z (2007) About a possible valorisation in cementitious materials of polluted sediments after treatment. Cement Concr Compos 29(4): 270-278. https://doi.org/10.1016/j.cemconcomp.2006.11.012

2. Amar M, Benzerzour M, Kleib J, Abriak N-E (2021) From dredged sediment to supplementary cementitious material: characterization, treatment, and reuse. Int J Sediment Res 36(1): 92-109. https://doi.org/10.1016/j.ijsrc.2020.06.002 
3. Benamar A, Tian Y, Portet-Koltalo F, Ammami MT, Giusti-Petrucciani N, Song Y, Boulange-Lecomte C (2019) Enhanced electrokinetic remediation of multi-contaminated dredged sediments and induced effect on their toxicity. Chemosphere 228: 744-755. https://doi.org/10.1016/j.chemosphere.2019.04.063

4. Benzerzour M, Amar M, Abriak N-E (2017) New experimental approach of the reuse of dredged sediments in a cement matrix by physical and heat treatment. Construct Build Mater 140: 432-444. https://doi.org/10.1016/j.conbuildmat.2017.02.142

5. Cappuyns V, Deweirt V, Rousseau S (2015) Dredged sediments as a resource for brick production: possibilities and barriers from a consumers' perspective. Waste Manage 38: 372-380. https://doi.org/10.1016/j.wasman.2014.12.025

6. Chen M, Cui J, Ding S, Gong M, Ren M, Tsang DC (2018) Successful control of internal phosphorus loading after sediment dredging for 6 years: a field assessment using high-resolution sampling techniques. Sci Total Environ 616: 927-936. https://doi.org/10. 1016/j.scitotenv.2017.10.227

7. Ding S, Zhao Z, Tian Q, Li D, Ren H (2021) Effect of iron-carbon micro-electrolysis-fenton on the dewatering performance of sludge. Environ Sci Pollut R. https://doi.org/10.1007/ s11356-021-13514-4

8. Douglas GB, Hamilton DP, Robb MS, Pan G, Spears BM, Lurling M (2016) Guiding principles for the development and application of solid-phase phosphorus adsorbents for freshwater ecosystems. Aquat Ecol 50(3): 385-405. https://doi.org/10.1007/s10452-0169575-2

9. Dubois V, Abriak NE, Zentar R, Ballivy G (2009) The use of marine sediments as a pavement base material. Waste Manage 29(2): 774-782. https://doi.org/10.1016/j.wasman.2008.05.004

10. Gu C, Li F, Xiao J, Chu S, Song S, Wong MH (2019) A novel submerged Rotala rotundifolia, its growth characteristics and remediation potential for eutrophic waters. Sci Rep 9: 14855. https://doi.org/10.1038/s41598-019-51508-y

11. Han Y, Li H, Liu M, Sang Y, Liang C, Chen J (2016) Purification treatment of dyes wastewater with a novel micro-electrolysis reactor. Sep Purif Technol 170: 241-247. https://doi.org/ 10.1016/j.seppur.2016.06.058

12. Jin Y, Huang S, Wang Q, Gao M, Ma H (2019) Ceramsite production from sediment in Beian River: characterization and parameter optimization. R Soc Open Sci 6: 190197. https://doi.org/10.1098/rsos.190197

13. Lafhaj Z, Samara M, Agostini F, Boucard L, Skoczylas F, Depelsenaire G (2008) Polluted river sediments from the North region of France: treatment with Novosol process and valorization in clay bricks. Constr Build Mater 22: 755-762. https://doi.org/10.1016/ j.conbuildmat.2007.01.023

14. Lim YC, Lin SK, Ju YR, Wu CH, Lin YL, Chen CW, Dong CD (2019) Reutilization of dredged harbor sediment and steel slag by sintering as lightweight aggregate. Process Saf Environ 126: 287-296. https://doi.org/10.1016/j.psep.2019.04.020

15. Ma X, Li X, Li J, Ren J, Chi L, Cheng X (2021) Iron-carbon could enhance nitrogen removal in Sesuvium portulacastrum constructed wetlands for treating mariculture effluents. Bioresour Technol 325: 124602. https://doi.org/10.1016/j.biortech.2020.124602

16. Mymrin V, Stella JC, Scremim CB, Pan RC, Sanches FG, Alekseev K, Pedroso DE, Molinetti A, Fortini OM (2017) Utilization of sediments dredged from marine ports as a principal component of composite material. J Clean Prod 142: 4041-4049. https://doi.org/10.1016/ j.jclepro.2016.10.035

17. Oldenborg KA, Steinman AD (2019) Impact of sediment dredging on sediment phosphorus flux in a restored riparian wetland. Sci Total Environ 650: 1969-1979. https://doi.org/10.1016/ j.scitotenv.2018.09.298

18. Patmont CR, Ghosh U, LaRosa P, Menzie CA, Luthy RG, Greenberg MS, Cornelissen G, Eek E, Collins J, Hull J, Hjartland T, Glaza E, Bleiler J, Quadrini J (2015) In situ sediment treatment using activated carbon: a demonstrate sediment cleanup technology. Integr Environ Asses 11(2): 195-207. https://doi.org/10.1002/ieam.1589

19. Puttonen I, Kohonen T, Mattila J (2016) Factors controlling phosphorus release from sediments in coastal archipelago areas. Mar Pollut Bull 108(1-2): 77-86. https://doi.org/10.1016/ j.marpolbul.2016.04.059

20. Qi Y, Dai B, He S, Wu S, Huang J, Xi F, Ma Y, Meng M (2016) Effect of chemical constituents of oxytetracycline mycelia residue and dredged sediments on characteristics of ultra-lightweight ceramsite. J Taiwan Inst Chem E 65: 225-232. https://doi.org/10.1016/j.jtice.2016.05.005

21. Schindler DW, Carpenter SR, Chapra SC, Hecky RE, Orihel DM (2016) Reducing phosphorus to curb lake eutrophication is a success. Environ Sci Technol 50(17): 8923-8929. https://doi.org/10.1021/acs.est.6b02204

22. Schonach P, Nygren NA, Tammeorg O, Heikkinen M, Holmroos H, Massa I, Niemisto J, Tapio P, Horppila J (2018) The past, present, and future of a lake: interdisciplinary analysis of long-term restoration. Environ Sci Policy 81: 95-103.

https://doi.org/10.1016/j.envsci. 2017.12.015

Page 8/13 
23. SEPA (2002) Water and Wastewater Monitoring Methods, fourth ed. Chinese Environmental Science Publishing House, Beijing

24. Shen Y, Zhuang L, Zhang J, Fan J, Yang T, Sun S (2019) A study of ferric-carbon micro-electrolysis process to enhance nitrogen and phosphorus removal efficiency in subsurface flow constructed wetlands. Chem Eng J 359: 706-712. https://doi.org/10.1016/ j.cej.2018.11.152

25. Shih K, White T, Leckie JO (2006) Spinel formation for stabilizing simulated nickel-laden sludge with aluminum-rich ceramic precursors. Environ Sci Technol 40: 5077-5083. https://doi.org/10.1021/es052324z

26. Song Z, Zhang W, Gao H, Wang D (2020) Comprehensive assessment of flocculation conditioning of dredged sediment using organic polymers: dredged sediment dewaterability and release of pollutants. Sci Total Environ 739: 139884. https://doi.org/10.1016/j.scitotenv. 2020.139884

27. Tay JH, Show KY, Hong SY (2001) Reuse of industrial sludge as construction aggregates. Water Sci Technol 44(10): $269-272$. https://doi.org/10.2166/wst.2001.0638

28. Wang L, Kwok JSH, Tsang DCW, Poon C-S (2015) Mixture design and treatment methods for recycling contaminated sediment. J Hazard Mater 283: 623-632. https://doi.org/10.1016/ j.jhazmat.2014.09.056

29. Wu M, Sun X, Huang S, Tang X, Scholz M (2012) Laboratory analyses of nutrient release processes from Haihe River sediment. Int J Sediment Res 27(1): 61-72. https://doi.org/ 10.1016/S1001-6279(12)60016-X

30. Xing W, Li D, Li J, Hu Q, Deng S (2016) Nitrate removal and microbial analysis by combined micro-electrolysis and autotrophic denitrification. Bioresour Technol 211: 240-247. https://doi.org/10.1016/j.biortech.2016.03.044

31. Xu GR, Zou JL, Li GB (2009) Ceramsite obtained from water and wastewater sludge and its characteristics affected by $\left(\mathrm{Fe}_{2} \mathrm{O}_{3}+\mathrm{CaO}+\mathrm{MgO}\right) /\left(\mathrm{SiO}_{2}+\mathrm{Al}_{2} \mathrm{O}_{3}\right)$. Water Res 43(11): 2885-2893. https://doi.org/10.1016/j.watres.2009.03.046

32. Yang Z, Ma Y, Liu Y, Li Q, Zhou Z, Ren Z (2017) Degradation of organic pollutants in near-neutral pH solution by Fe-C microelectrolysis system. Chem Eng J 315: 403-414. http://dx.doi.org/10.1016/j.cej.2017.01.042

33. Yu J, Ding S, Zhong J, Fan C, Chen Q, Yin H, Zhang L, Zhang Y (2017) Evaluation of simulated dredging to control internal phosphorus release from sediments: focused on phosphorus transfer and resupply across the sediment-water interface. Sci Total Environ 592: 662-673. https://doi.org/10.1016/j.scitotenv.2017.02.219

34. Zhang W, Feng H, Chang J, Qu J, Xie H, Yu L (2009) Heavy metal concentration in surface sediments of Yangtze river intertidal zone: an assessment from different indexes. Environ Pollut 157(5): 1533-1543. https://doi.org/10.1016/j.envpol.2009.01.007

35. Zheng X, Jin M, Zhou X, Chen W, Lu D, Zhang Y, Shao X (2019) Enhanced removal mechanism of iron carbon micro-electrolysis constructed wetland on C, N, and P in salty permitted effluent of wastewater treatment plant. Sci Total Environ 649: 21-30. https://doi.org/10.1016/j.scitotenv. 2018.08.195

36. Zhong JC, You BS, Fan CX, Li B, Zhang L, Ding SM (2008) Influence of sediment dredging on chemical forms and release of phosphorus. Pedosphere 18(1): 3-44. https://doi.org/10.1016/ S1002-0160(07)60100-3

37. Zhou QW, Zhu H, Banuelos G, Yan B, Liang Y, Yu J, Li H (2017) Impacts of vegetation and temperature on the treatment of domestic sewage in constructed wetlands incorporated with ferric-carbon micro-electrolysis material. Int J Phytoremediat 19(10): 915-924. https://doi.org/ 10.1080/15226514.2017.1303811

\section{Figures}




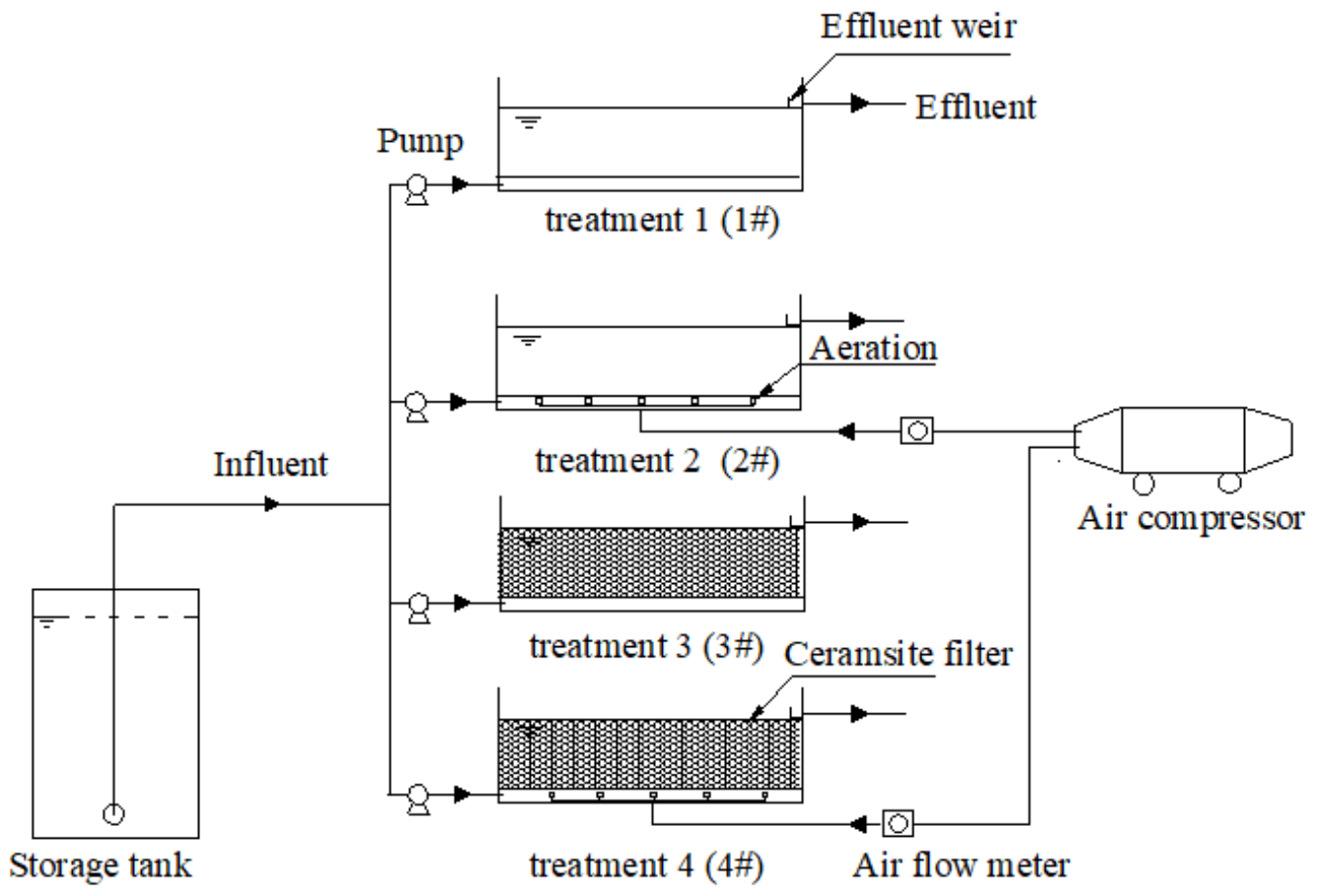

\section{Figure 1}

Schematic diagram of the biofilter system. 

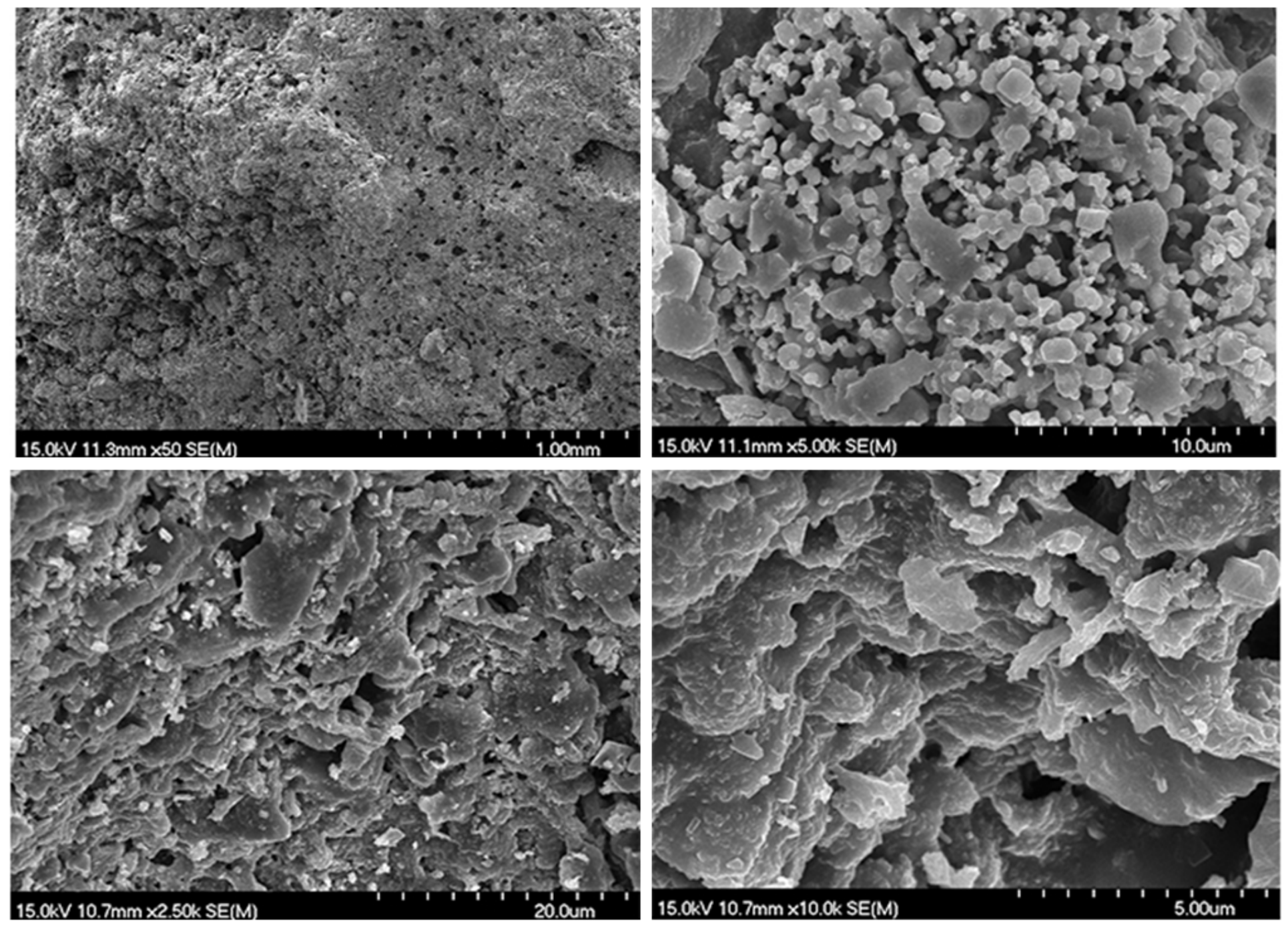

Figure 2

SEM of surface and cross section of the filter.
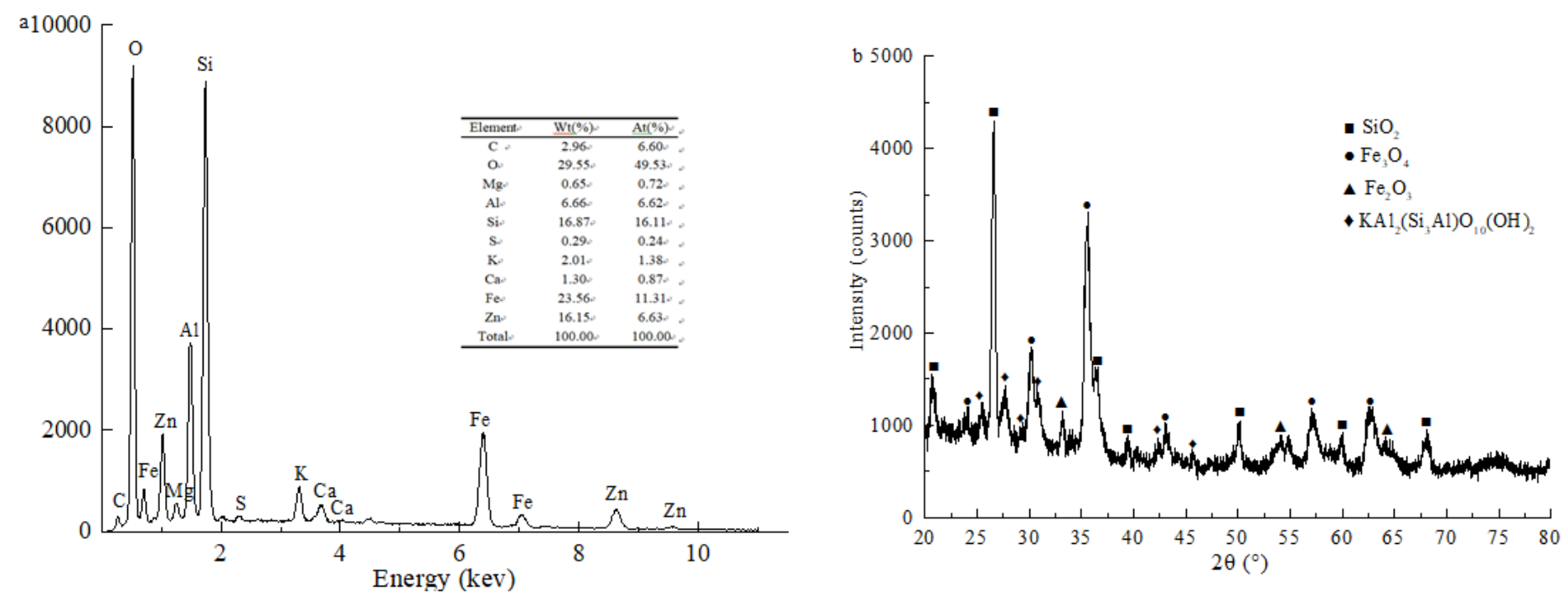

Figure 3 
EDS (a) and XRD (b) spectrum of the filter.

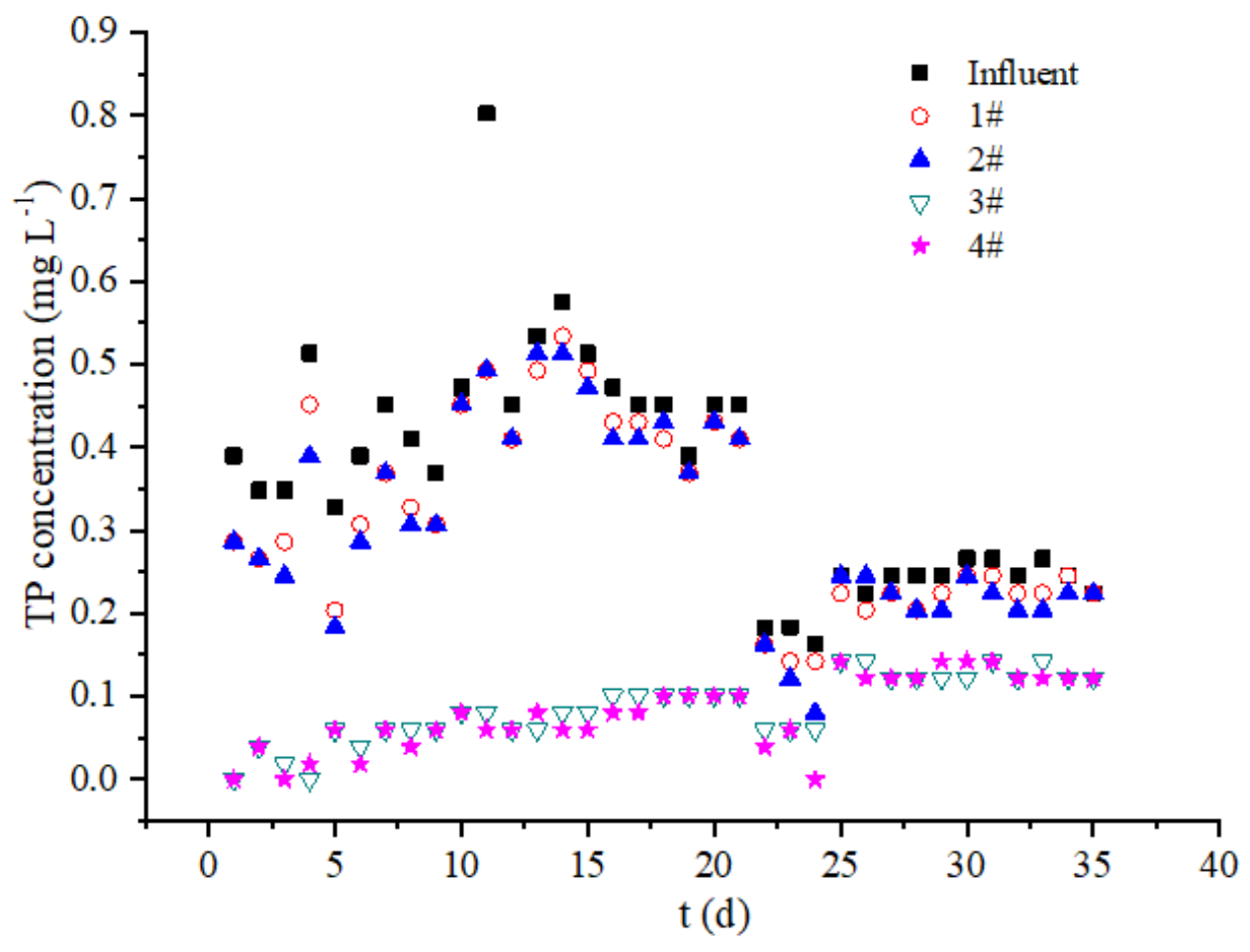

Figure 4

Total phosphorus concentration variations in the influent and effluent of the biofilter system.

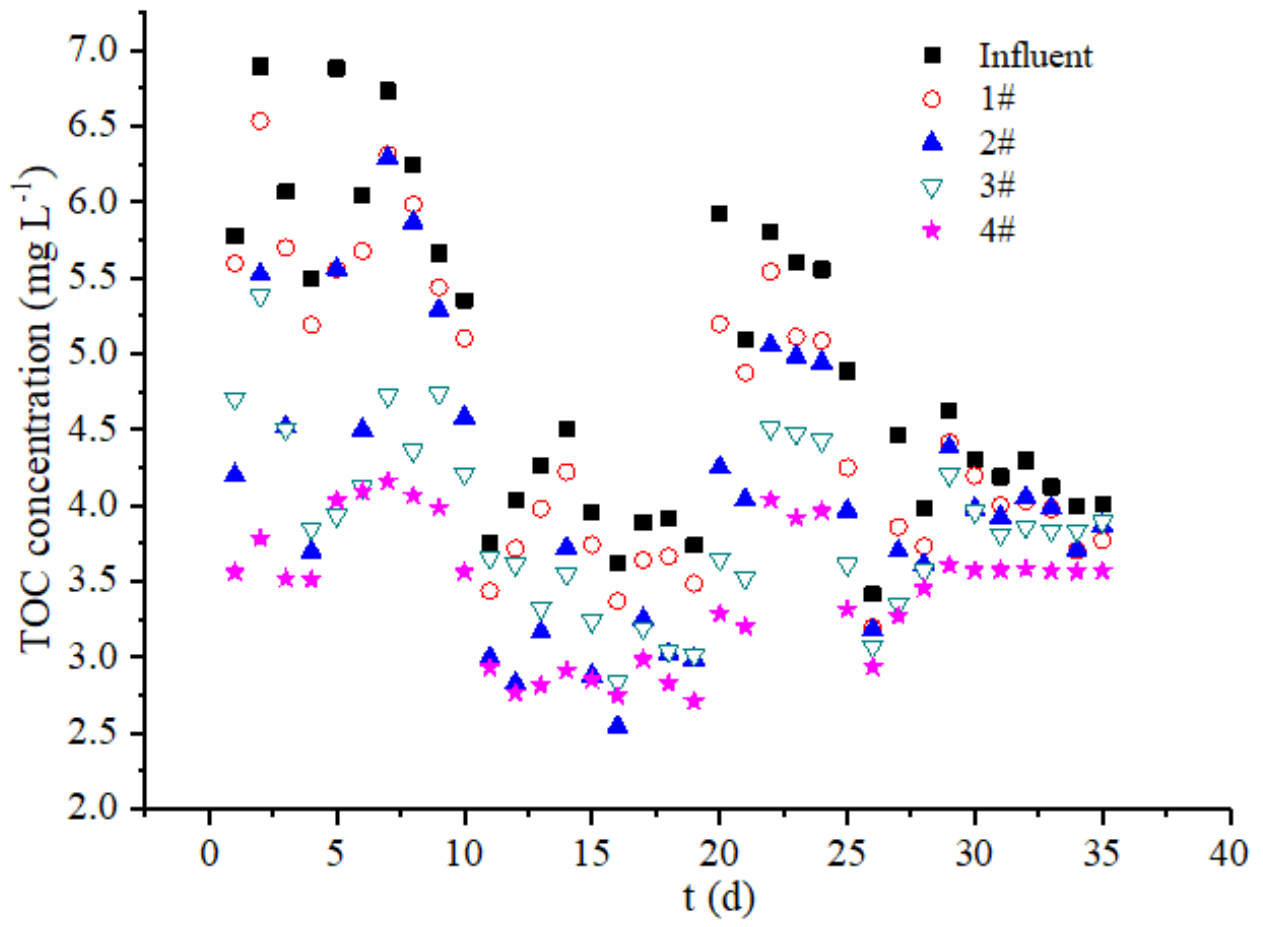

Figure 5

TOC concentration variations in the influent and effluent of the biofilter system. 

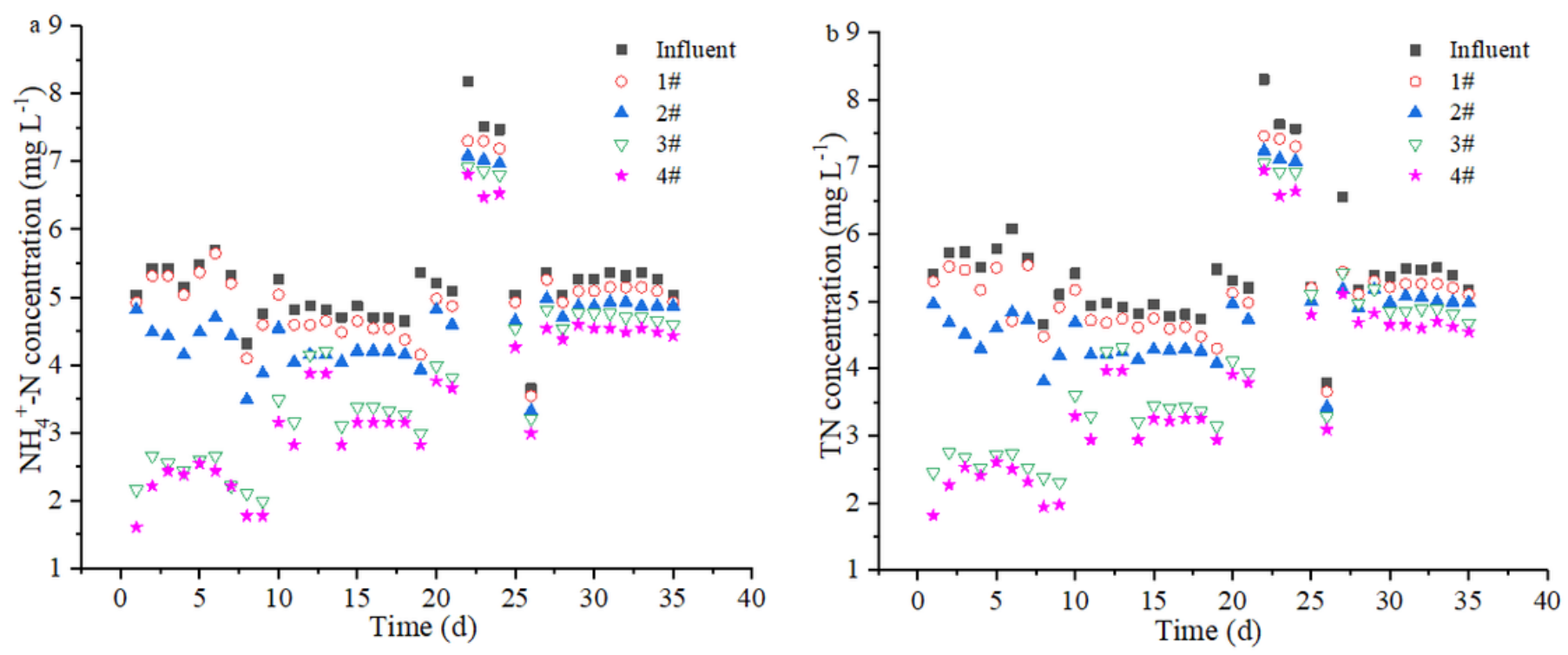

Figure 6

Concentration variations of ammonium nitrogen (a) and total nitrogen (b) in the influent and effluent of the biofilter system. 